\title{
Ouvir a música como uma experiência imprescindível para se fazer musicologia
}

Ivan Vilela

(USP)

\begin{abstract}
Resumo: O presente artigo reafirma a importância de se trabalhar com as fontes primárias quando se pode ter acesso a elas em uma pesquisa musicológica. Partindo de uma diferenciação postulada por Jorge Larrosa Bondía onde a informação sempre se encontra em oposição à experiência, a informação nos nutre e a experiência nos perpassa. Quem possui a informação não busca a experiência. Atualmente uma parte expressiva dos artigos sobre musicologia tem sido construído a partir da leitura de textos e não da audição das músicas em foco perpetuando, muitas vezes, equívocos das visões dos que primeiro escreveram. A partir do ouvir música aponta-se como é possível percebermos muitas das mudanças ocorridas no seio da MPB ao longo das décadas, mas que nunca foram sequer citadas. A atitude de não se trabalhar com as fontes primárias ajuda na perpetuação de cânones uma vez que sempre se reafirmam, nos textos, visões sobre temas que muito já foram debatidos. Assim, a música do cinema estadunidense nos anos 1940, a bossa nova, o samba, a canção de protesto, o clube da esquina quando pesquisadas em suas fontes primárias podem nos apontar novos caminhos.
\end{abstract}

Palavras-chave: música popular, fruição, musicologia, fontes primárias

\section{LISTENING TO MUSIC AS A NECESSARY EXPERIENCE TO MAKE MUSICOLOGY}

\begin{abstract}
This article reaffirms the importance of working with primary sources when you can have access to them on a musicological research. Starting from a postulated differentiation by Jorge Larrosa Bondia where information is always in opposition to the experience, information nourishes us and experience in pervades. Who owns the information does not seek the experience. Currently a significant part of the articles on musicology has been built from the reading of texts and not hearing the music in focus perpetuating, often misunderstanding the views of those who first wrote. From listening to music to points as you can perceive a lot of changes within the MPB over the decades but were never even mentioned. The attitude of not working with primary sources helps in the perpetuation of canons as it always reassert themselves in texts, views on issues that have been much discussed. Thus, the American film music in the 1940s, bossa nova, samba, the song of protest, the corner club when surveyed in their primary sources can point us new ways.
\end{abstract}

Keywords: popular music, fruition, musicology, primary sources. 
A informação não é experiência. E mais, a informação não deixa lugar para a experiência, ela é quase o contrário da experiência, quase uma antiexperiência. Por isso a ênfase contemporânea na informação, em estar informados, e toda a retórica destinada a constituir-nos como sujeitos informantes e informados; a informação não faz outra coisa que cancelar nossas possibilidades de experiência. O sujeito da informação sabe muitas coisas, passa seu tempo buscando informação, o que mais o preocupa é não ter bastante informação; cada vez sabe mais, cada vez está melhor informado, porém, com essa obsessão pela informação e pelo saber (mas saber não no sentido de "sabedoria", mas no sentido de "estar informado"), o que consegue é que nada Ihe aconteça [...] O saber de experiência se dá na relação entre o conhecimento e a vida humana. De fato, a experiência é uma espécie de mediação entre ambos. É importante, porém, ter presente que, do ponto de vista da experiência, nem "conhecimento" nem "vida" significam o que significam habitualmente (Bondía, 2002, p. 26 e 27).

Este artigo pretende tratar genericamente de algumas questões que tem surgido na medida em que os estudos sobre a musicologia popular aumentam.

Tornou-se corriqueiro a prática de realizar estudos musicológicos tomando como fonte única a literatura que existe a respeito, esquecendo-se da mais atávica de todas as fontes: a música em si. Ouvir a música em estudo é artefato imprescindível na elaboração de algum texto sobre música popular. No entanto, repito, reparamos que cada vez mais surgem artigos musicológicos que têm na literatura a respeito as principais bases de conteúdo de seus trabalhos.

Ora, as impressões reflexivas registradas de forma escrita são importantes sim, na construção da imagem e do conhecimento a ser estudado, mas elas não prescindem da audição dos discos, as fontes primárias e principais desses estudos, que sequer são, as vezes, relevadas. Assim, perpetuam-se as visões dos que primeiro escreveram sobre um tema, as quais são fixadas; visões essas que nem sempre foram as mais corretas, mas, pelo peso acadêmico de quem as escreveu tornam-se a matéria prima desses estudos. Ou seja, mais que o acontecimento musical perpetua-se a percepção de alguns sobre esse acontecimento.

Há ainda a argumentação de que a canção é um fenômeno polissêmico e, se relacionando com o nosso cotidiano, pode então ser lida por diversas áreas do conhecimento humano. Estou de acordo, até aí. Sempre o historiador, o cientista 
social, o jornalista, o linguista, o crítico literário, o geógrafo e outros estudiosos do conhecimento humano terão contribuições a fazer no entendimento da canção. No entanto, não devemos esquecer que a música, como seu principal veículo, deve também, entrar nos méritos das questões musicológicas.

Essa cegueira, digo, surdez, fez um pesquisador da MPB tratar o Clube da Esquina como "um estilhaço pós-tropicalista". Me ocorre, num caso desses que esta surdez pode ser as vezes conveniente para que se reforce o ponto de vista do autor, assunto que trataremos adiante. Primeiro, preciso retornar a um ponto remoto que trata da nossa formação cultural.

\section{Música e Cultura Popular}

Conforme comentei na introdução do livro sobre música caipira "Cantando a Própria História - música caipira e enraizamento", ao longo da formação de nossa cultura popular, isso nos séculos XVIII e XIX, a elite brasileira olhava para fora do país tentando ser europeia, deixando assim de presenciar e experimentar o processo que gerou a mais exuberante cultura popular do planeta. Ainda hoje, essa elite olha para essa cultura e para o povo da qual faz parte e não os reconhece como seus.

Desde então, vivemos transitando entre a absorção, a xenofilia e a xenofobia. Sendo a cultura brasileira uma cultura de soma, não nos cabe sermos xenófobos, pois deporíamos contra a nossa própria formação cultural. Entretanto não nos cabe sermos xenófilos, pois isso só acentuaria nossa crise de desenraizamento enquanto povo.

Notemos que os países do chamado primeiro mundo tratam suas culturas populares como assunto de segurança nacional, percebendo nelas o berço de seus mitos de origem e em suas manifestações aquilo que faz todos se sentirem parte de um todo, de um povo, de uma mesma nação. E quando pensamos como um só povo, andamos juntos.

Um povo desenraizado, sem raízes, sem passado, sem cultura é campo fecundo para um processo de crise moral, falta de educação generalizada, quebra 
de ritos como o respeito aos velhos e à cidadania. Curiosamente esses são temas que atualmente fazem parte da ordem do dia brasileiros. Estaremos vivendo um estado de desenraizamento?

Um miserável vivente em seu lugar de origem, por mais pobre que seja, conta com uma rede de solidariedade que o sustenta e também um lastro histórico, de sua própria biografia e história pessoal, que o mantém íntegro e longe de cometer algum desvario contra os outros e consequentemente contra si próprio. Este mesmo vivente, longe deste seu lugar de origem, perdido numa grande cidade, corre o risco de, com a perda seus valores primordiais, perder também a sua dignidade.

Com o advento da República no Brasil outro fato histórico exacerbou o distanciamento de nossas raízes: a implantação do ideal positivista que, entre outras coisas, preconizava a prevalência do saber erudito sobre o saber popular.

O saber erudito advindo de uma nova concepção de ciência e como resultado prático dos processos de secularização e racionalização industrial que se instauraram no Brasil, principalmente a partir do século XX, criou confrontos com o saber tradicional. As pessoas de camadas mais populares viram-se cada vez mais envolvidas em situações que exigiam delas novas atitudes. Atitudes essas incompatíveis com os modelos tradicionais de comportamento.

o último quartel do século passado (XIX) marca o início da revolução que se iria operar, pois as campanhas abolicionistas e a urbanização paulatina das condições de existência iriam deitar por terra as relações patrimonialistas e a concepção tradicional do mundo correspondente (...) Então começa a desagregação da cultura popular. O 'escravo' e o 'homem do povo' desconheciam quase completamente os motivos e os padrões ideais que tornavam atitudes, técnicas e instituições tradicionais valores socialmente pouco conspícuos e desejáveis nas camadas dominantes" (Fernandes, 1979, p. 31).

Observando mais a história e formação da América Espanhola surgiu-me uma indagação:

O projeto de colonização da América Espanhola pressupunha a criação de uma nova Espanha nas terras americanas. Desta forma foram trazidas condições para formar um arcabouço cultural que desse conta da formação do povo 
espanhol nas Américas. Lembremos que as primeiras universidades de colônias como Peru, México e Argentina datam da metade do século XVI e início do século XVII. ${ }^{1}$ Desta forma o saber erudito conviveu com o saber popular desde o início da colonização dessas regiões.

Portugal tinha um outro princípio: o de manter a sua colônia, o Brasil, longe do acesso a esses bens. A primeira universidade do Brasil, a Universidade de São Paulo, data de 1934. Mesmo a imprensa só foi liberada no Brasil com a vinda da Família Real, em 1808. Até 1821 havia uma censura prévia sobre tudo o que era editado e a tipografia da Imprensa Régia era a única existente no Brasil.

O que vemos diante dessa situação é que o Brasil teve a sua formação, em grande parte de seu tempo de vida, calcada na construção de um saber popular, oral, longe dos livros. Assim, expressiva parte da população, formada por homens livres pobres e escravos, adquiriu seus conhecimentos através de um saber móvel, que se adaptava às diversas situações que se Ihes eram apresentadas.

El relato oral es móvil, lo que impide su esclerosamiento. A diferencia del libro no caduca: se transforma. Es un medio de transmisión de conocimientos que en mayor o menor grado vehicula una carga subjetiva, la que incluye los fermentos que permitieron al mito cambiar de máscara, responder a las nuevas situaciones (Colombres, 1995, p. 139).

Desta maneira, fica mais fácil entendermos o gigantismo da cultura popular brasileira no que toca à diversidade de expressões, pois todo o saber acessado, escrito, em pequena parte, e oral, em grande parte era entendido a partir das percepções pessoais, inerentes ao arcabouço cultural pessoal de cada vivente ou grupo que o acessava.

Nesse ambiente de fervilhar de informações vindas de fora com europeus, povos diversos da África e povos diversos da terra, os índios, a música popular foi construída. Mais que isso, essa música, desde sua gênese, tornou-se a porta-voz dos anseios e acontecimentos ocorridos com esses povos que tinham nela uma maneira de registrar a sua história.

\footnotetext{
${ }^{1}$ Universidade Nacional de San Marcos, no Peru, 1551, Universidade Nacional Autônoma do México, 1551 e Universidade Nacional de Córdoba, 1613.
} 
Sempre que lemos a música popular é cautelar que não a desvencilhemos de seu arcabouço cultural popular.

Uma parte expressiva de nossos autores musicais do século XX eram “analfabetos musicais" e em grande parte advindos de camadas pobres como é o caso dos compositores de samba dos anos 1930, das duplas caipiras e, mesmo mais perto de nós, alguns compositores dos anos 1960 e 70.

\section{Dinâmica Cultural no Brasil}

A título de imagem, pensemos a cultura brasileira como um grande caldeirão fervente que a tudo dissolve e mistura. Este caldeirão foi mantido ao longo de nossa formação cultural e, no século XX, pela escola pública e pela rua como um espaço lúdico de trocas.

Na escola pública, ricos e pobres se encontravam, iguais, de uniforme e, a priori, chances iguais eram dadas a todos. A distribuição deste saber erudito era igual para todos.

A rua como um espaço de trocas simbólicas sempre foi o espaço lúdico das crianças brasileiras em todas as cidades. Nos jogos e brincadeiras aprendiamse noções de convívio, motricidade, lateralidade, hierarquia, coletividade, regras, tolerância, sobrevivência, trânsito em meios diferentes e possibilidades de relacionamentos diversos.

\section{Diversidade no perceber o mundo}

Não havia separação entre pobreza e cultura. Cartola foi um homem pobre, mas não inculto. Era educado, polido, fino, se quisermos usar alguns adjetivos que retratam este perfil. E como ele muitos outros homens e mulheres brasileiros carregavam cultura independente de sua situação financeira. Meu pai foi um homem pobre e era culto. De alguma forma o acesso a bens culturais relativos à formação de nosso povo eram de fácil acesso a todos pelas vias da escola e das ruas. 
A partir do golpe militar e consequente derrocada do sistema público de ensino no Brasil - isto concomitante ao crescimento e violência nas grande cidades e agora nas pequenas, decorrente, em parte, da má distribuição de renda e acessos - essas trocas começaram a deixar de existir. Se antes pobres e ricos se encontravam no espaço da escola e da rua trocando bens culturais entre estratos sociais, hoje isto não acontece.

O menino de muitas posses estuda em uma escola particular e de nível de ensino elevado para cursar uma universidade pública, que na sua grande maioria são as melhores. O menino de poucas posses faz o ensino básico em uma escola pública e só encontra possibilidades de cursar uma universidade particular, normalmente de nível inferior ao da universidade pública.

Estes estratos sociais não mais se encontram ou se encontram de maneira reduzida.

No caso da rua, esta deixando de ser o espaço lúdico, das trocas, foi transferido às pré-escolas esta função. Sendo a rua um espaço agora do não convívio, a tarefa de entretenimento das crianças foi dada, em parte, à televisão.

Infelizmente não recordo detalhes de artigo que li acerca de um mestrado defendido no Rio de Janeiro, na área de Educação que mostrava como as crianças de pré-escolas da Baixada Fluminense tinham uma predileção pelas professoras loiras e não negras e, ainda, que o tempo de concentração nas aulas não chegava a dez ou quinze minutos. Na realidade o mesmo tempo da programação televisiva antes do intervalo para propagandas. As apresentadoras de programas infantis na TV são sempre brancas e loiras. Vemos aqui a televisão regendo a capacidade de aprendizado das crianças que a ela ficam sujeitas.

Ora, o caldeirão que era mantido pelas trocas e pela assimilação e digestão de tudo que aqui chegava, de fora, passou a diminuir seu volume.

Pensemos: quando o rock chegou ao Brasil e foi assimilado por todos, acabou virando material comum e pulou para dentro do caldeirão. Este, fervente, o amalgamou a vários aspectos da cultura brasileira.

Desta forma, The Beatles e todos os outros sons que aqui chegavam foram manifestos como Jovem Guarda (este mais próximo das origens), Tropicália (Mutantes), Clube da Esquina, Raul Seixas, Guilherme Arantes, O Terço, Casa das 
Máquinas, Rita Lee, Made in Brazil, Walter Franco e muitas outras vertentes. Até Alceu Valença, embora este diga que não gosta de rock.

Os efeitos específicos das forças materiais globais dependem diretamente da maneira como são mediados em esquemas culturais locais. ${ }^{2}$

Com a supressão da escola pública e da rua como espaço lúdico de trocas, este caldeirão foi se esvaziando e o material de trocas físicas e simbólicas de nosso povo, como resposta ao que aqui chegava, diminuiu.

Hoje, manifestações da cultura popular urbana paulistana como o hip-hop e o rap, tiveram em sua gênese uma semelhança muito intensa com suas matrizes estadunidenses. Com o tempo e a ação cultural de grupos da periferia essa mistura foi se processando dando agora um caráter diferenciado e singular a essas manifestações.

Mas não podemos deixar de perceber que diminuiu nosso material de trocas e interações físicas e simbólicas como resposta de reação e mistura ao que aqui chega de fora. Este empobrecimento cultural tira a nossa habilidade em lidar com complexidades e assimilá-las, pois nosso universo imagético tornou-se menor. $^{3}$

Isto acarretou em dificuldades gerais de acessar expressões artísticas mais elaboradas. Nos tornamos presa muito fácil à imposição de uma música de consumo de baixa qualidade, afinada a um projeto de uniformização cultural e imposta ao alto custo de propinas aos meios de comunicação.

De certa forma, incultura e desconhecimento acerca da cultura brasileira tornaram-se vias de muitas mãos afetando hoje pobres e ricos.

A pergunta que me ronda é: será que se mantivéssemos nosso arcabouço cultural denso, como sempre foi, consumiríamos em grande escala este tipo de produto cultural, descartável, de alta vendagem e rápido esquecimento? Estrelas cadentes?

\footnotetext{
${ }^{2}$ Marshall Sahlins, em palestra proferida na UNICAMP em 1988, defendeu a ideia que as forças de movimento hegemônico no mundo não conseguem seu intento porque estão sujeitas a adaptações em esquemas culturais locais.

${ }^{3}$ Ideia apresentada pela educadora Gabriela Jahnel, esta da falta de habilidade em lidar com complexidades.
} 


\title{
Ouvindo música popular
}

\begin{abstract}
Depois de assistir a uma aula ou a uma conferência, depois de ter lido um livro ou uma informação, depois de ter feito uma viagem ou de ter visitado uma escola, podemos dizer que sabemos coisas que antes não sabíamos, que temos mais informação sobre alguma coisa; mas, ao mesmo tempo, podemos dizer também que nada nos aconteceu, que nada nos tocou, que com tudo o que aprendemos nada nos sucedeu ou nos aconteceu (Bondía, 2002, p. 22).
\end{abstract}

A experiência de ouvir música pode nos trazer revelações importantes além de ampliar o nosso universo cultural através da fruição.

Hoje, a música é um ruído de fundo da sociedade moderna, ouvimos música no supermercado, no consultório, em todos os lugares onde estamos fazendo outras coisas que não propriamente ouvir música. Ela deixou de ser percebida como algo que realmente mereça a nossa total atenção e possa nos transformar.

\section{A Canção}

Trata-se normalmente por canção uma estrutura musical que tenha letra e melodia sendo essas inseparáveis na concepção deste conceito. Desta maneira, seria difícil pensarmos em uma canção instrumental. Assim, diversas músicas instrumentais, verdadeiras canções, surgidas no Brasil, não se enquadrariam neste conceito de canção.

Ora, ao olharmos para toda a produção de música europeia nos períodos barroco e sobretudo clássico e romântico, perceberemos, principalmente a partir de Beethoven, que o que caracterizou a produção musical europeia de concerto foi a ideia de desenvolvimento de um ou mais temas até às raias de suas possibilidades.

Como exemplo claro e fácil, temos o primeiro movimento da quinta sinfonia de Beethoven, onde um motivo musical é desenvolvido por caminhos antes inimagináveis. Este conceito de desenvolvimento e expansão de uma ideia marcou a própria estrutura da forma sonata. 


\section{Exemplo 1}

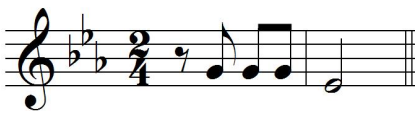

A expansão de uma ou mais ideias musicais marcou a produção europeia do século XIX.

Voltando à canção, não seria mais razoável pensarmos nela como uma estrutura musical que resiste à expansão? Seja ela cantada ou instrumental? Isto pode ter se dado por vários fatores dentre os quais o espaço sonoro cabível em um disco de 78rpm, mas esta indagação não vem agora ao caso.

Pensando a canção como uma estrutura musical que resiste à expansão e pode ser multiformal com uma só parte, duas, três e até mais como algumas canções do disco Milagre dos Peixes (1973), de Milton Nascimento, incluímos parte expressiva da produção musical brasileira e internacional instrumental neste conceito. O próprio disco Milagre dos Peixes que teve grande parte de suas letras censuradas não deixaria de ser um disco de canção, que é a natureza real de como foi concebido inicialmente.

\section{Fluxos musicais EUA - Brasil}

A chamada Década de Ouro do rádio no Brasil marca uma mudança substancial não só na qualidade e tratamento da produção musical como também na diversidade de compositores presentes.

Temos aí uma junção positiva do disco sendo divulgado por um aparato de comunicação, o rádio, fortalecido por Getúlio em seu projeto de valorização da cultura popular urbana em contraposição a uma cultura rural que remetia à política ruralista à qual se opôs, a do Café com Leite.

A Rádio Nacional, intencionalmente ou não, contribuiu para o homogeneização do samba como a música de expressão nacional. 
Neste período marcado pelos anos 1930 a 1950, a presença da cultura dos EUA fortaleceu-se a cada instante no Brasil. Filmes, discos, programas culturais, aproximação com artistas famosos do Brasil (Zequinha de Abreu, Ary Barroso, Carmen, Miranda, Dorival Caymmi, Luiz Gonzaga). ${ }^{4}$

Pela via do cinema começaram a chegar filmes com trilhas sonoras densas e bem construídas. Em conversa informal, Roberto Gnatalli ${ }^{5}$ contou-me que quando chegava um musical novo dos EUA, seu tio, Radamés Gnatalli (19061988), tinha a incumbência de ir à Cinelândia na primeira sessão e só sair de lá quando tivesse a trilha sonora toda escrita para a Rádio Nacional que fazia, em primeira mão, uma apresentação radiofônica da trilha sonora de tal filme antes mesmo de chegarem ao Brasil os discos e as partituras. Cabe aqui um depoimento de Radamés que, mais que se opor, amplia esta colocação Roberto Gnatalli:

Em 1935, Orlando Silva requisitou-Ihe alguns arranjos de cordas para seu disco. O maestro aceitou, sem saber que seria o início de sua batalha contra os críticos: "Gostam do que é bom. O Orlando Silva, que acabou sendo o primeiro a gravar música brasileira com orquestra sinfônica, vendeu toneladas de discos, apesar das reclamações contra meus arranjos. O acorde americano, como ficou conhecido o acorde de nona, agradou muito o público e, se também era utilizado no jazz, era porque os compositores de jazz ouviam Ravel e Debussy. Aqui ninguém nunca tinha ouvido o tal acorde em outro lugar a não ser em música americana, e vieram as críticas. Mas o povo não se deixou levar e assimilou muito bem a novidade" (Bresson, 1979, p. 26). ${ }^{6}$

É de se pensar, diante de tal fato, que esses procedimentos orquestrais construídos sobre a música popular estadunidense, diga-se de passagem, muito bem feitos, acabassem por influenciar as orquestrações de música popular brasileira de alguma forma, não?! Como uma via de duas mãos, a dos impressionistas e a do Jazz que também havia sido influenciado pelos impressionistas. O próprio Custódio Mesquita, um dos primeiros arranjadores

\footnotetext{
${ }^{4}$ Os anos 1940 são marcados por uma política de aproximação entre Brasil e EUA. Esta, chamada de política de boa vizinhança, empreendida pelos ÉUA, visava o apoio do Brasil aos aliados na Segunda Grande Guerra e já preparava o campo brasileiro para uma cada vez mais forte interferência e controle político, econômico e cultural dos EUA sobre o Brasil.

${ }^{5}$ Roberto Gnatalli, músico, professor e arranjador.

${ }^{6}$ Acessado no http://catalogos.bn.br/lc/musica/radames/noradio.htm, no dia 14/12/2014.
} 
orquestrais da música popular brasileira, tinha em seus arranjos evidências sonoras desta influência estadunidense.

Esta influência do cinema dos EUA sobre a música popular e sobre os costumes deve ter sido forte a ponto de Noel Rosa (1910-1937), incomodado com ela, na época, compor "Não Tem Tradução", de Noel, Ismael Silva e Francisco Alves, este último possivelmente ganhou a parceria para se dispor a gravar esta canção.

O cinema falado é o grande culpado da transformação

Dessa gente que sente que um barracão prende mais que o xadrez

Lá no morro, seu eu fizer uma falseta

A Risoleta desiste logo do francês e do Inglês

A gíria que o nosso morro criou

Bem cedo a cidade aceitou e usou

Mais tarde o malandro deixou de sambar, dando pinote

E só querendo o dançar o Foxtrote

Essa gente hoje em dia que tem a mania da exibição

Não entende que o samba não tem tradução no idioma francês

Tudo aquilo que o malandro pronuncia

Com voz macia é brasileiro, já passou de português

Amor lá no morro é amor pra chuchu

As rimas do samba não são I love you

E esse negócio de alô, alô boy e alô Johnny

Só pode ser conversa de telefone"

Esta composição já denota, com força, a presença da música popular dos EUA no Brasil, vinda, em parte expressiva, pela via dos musicais.

Se andarmos mais adiante, o Samba-Canção, que era uma música cantada com acompanhamento quase que primordialmente orquestral, já guardava uma estrutura formal muito próxima da canção estadunidense ${ }^{7}$. Principalmente o fato

\footnotetext{
${ }^{7}$ De maneira geral, a canção estadunidense, quando começa a ser orquestrada tem uma introdução, feita, as vezes, sobre uma das partes da música. Tem também um interlúdio instrumental de uma das partes, como se fosse um chorus para improvisação, lá chamado de bridge (ponte). A música brasileira não tinha esta característica. Nos sambas-canções fixou-se uma estrutura formal com "introdução, $A, B$, interlúdio instrumental com a parte $A$ ou B e cantor retornando a cantar A ou B e fim." Notemos que no caráter improvisação,
} 
de ter uma parte inteira (chorus) não para improviso como era usual no Jazz, mas para uma exposição instrumental escrita, arranjada, tais como nas canções cantadas com orquestra nos EUA.

É audível a influência dos impressionistas sobre a música popular, principalmente nas contribuições de Debussy nas harmonias e no alargamento das estruturas formais e de Ravel nas orquestrações. Não seria por mero acaso que Ravel se aproximou da música dos EUA orquestrando "Um Americano em Paris", dos irmãos Gershwin. Esta concepção de condução harmônica a partir de acordes com terças superpostas acima da tétrade fundamental (1, 3, 5 e 7) tornou-se a linguagem comum da música popular nos EUA e Brasil. ${ }^{8}$

O próprio depoimento de Radamés, citado anteriormente, aponta para este caminho. Notemos que a tradição do continente americano de norte a sul, calcado nos sopros e não nas cordas, ocorreu muito em decorrência das orquestras de negros escravos que eram orquestras de sopro ${ }^{9}$. Lembremos das bigbands nos EUA e as bandas corporativas no Brasil como a do Corpo de Bombeiros, regida inicialmente por Anacleto de Medeiros. Soma-se a isto a tradição de bandas de coreto por todo o Brasil.

Tal como o Samba, canção emergente no Brasil nas primeiras décadas do século XX, se apoiou no instrumental do Choro, a canção estadunidense também encontrou suporte no arcabouço instrumental das bigbands, no Jazz.

Ora, seria então razoável pensarmos que a influência da música dos EUA sobre a música brasileira se deu desde os anos 1930 e não a partir da Bossa Nova, como afirma o bordão corrente.

Se olharmos para a produção de música popular brasileira deste período veremos que ela não deixou de ser brasileira - lembremos do caldeirão citado acima - mas soube se valorizar incorporando em si elementos e conquistas musicais alcançadas antes pelos músicos dos EUA.

não vemos no Choro da época um músico improvisando toda uma parte (chorus), a improvisação era sempre coletiva e distribuída aos músicos sobre um mesmo chorus.

8 Não cito Cuba nem Argentina por falta de conhecimento específico sobre este determinado assunto, embora acredite que estas inovações à canção popular passassem. pelo cinema e pelos discos e partituras, a ser um material moderno comum a todos.

${ }^{9}$ Conferir Tinhorão, in História Social da Música Popular Brasileira. 
Sempre lembrando que a "moeda de troco" do Brasil, na época era muito forte, pois já havia se instaurado no Rio de Janeiro uma canção construída a partir das culturas populares rural e urbana, o Samba. Assim, a presença da música estadunidense no Brasil neste período serviu para avivar e fecundar e não descaracterizar o potencial criativo da Música Popular Brasileira.

\section{O Samba}

Como propus inicialmente, este é um artigo de genéricos, e tem mais o objetivo de, apontar tensões e dúvidas que propriamente resolvê-las.

Ao falarmos em Samba, pensamos numa sessão rítmica onde o acento cai habitualmente na cabeça do segundo tempo, o que fortalece o balanço e valoriza as síncopas. Será que ele sempre foi assim?

Na década de 1910, quando começou a ser gravado, o Samba teve como base o instrumental do choro. O Choro, inicialmente na expressão do Maxixe, foi sedimentado a partir de fusões rítmicas diversas como a Polca, de origem europeia, o Lundu, de origem afro-brasileira e a Habanera espanhola, segundo citam alguns autores como Mário de Andrade. ${ }^{10} \mathrm{O}$ fato é que como uma música primordialmente instrumental, o Choro serviu de base instrumental aos gêneros cantados que foram surgindo a partir da década de 1910. A própria música caipira se apoiou nesse instrumental em algumas das gravações realizadas por Raul Torres e Florêncio.

No período inicial de suas gravações que marcam a década de 1910 e 1920, o Samba, que teve sua expressão maior em Sinhô (José Barbosa da Silva, 1888-1930), manteve uma base rítmica muito próxima do maxixe e portanto, com o acento no primeiro tempo.

Vejamos a sessão rítmica da canção “Jura” de Sinhô, gravada em 1928 por Mário Reis:

\footnotetext{
10 Se era cubana ou espanhola a Habanera não cai no mérito das nossas questões neste momento.
} 


\section{Exemplo 2}

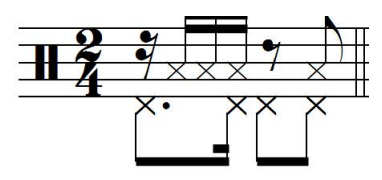

Em depoimento a Fernando Faro ${ }^{11}$, Ismael Silva (Mílton de Oliveira Ismael Silva, 1905-1978) disse que o samba maxixado, como era chamado o samba das décadas de 1910 e 20, não servia para se desfilar, marchando, por conta de sua rítmica que fazia as pessoas caminharem jogando o corpo para os lados. Ismael e outros jovens do Estácio, como Bide (Alcebíades Maia Barcellos, 1902-1975) e Marçal (Armando Vieira Marçal, 1902-1947), começaram a pensar numa rítmica que fosse compatível com o caminhar. ${ }^{12}$

Aí surge uma questão interessante. Se ouvirmos o samba "Nem é Bom Falar" de Ismael Silva e Nilton Bastos (1899-1931) ou o samba "Agora é Cinza", de Bide e Marçal, perceberemos que a rítmica desses sambas difere, e muito, de "Jura", de Sinhô ou de "Pelo Telefone" de Donga (Ernesto Joaquim Maria dos Santos, 1890-1974) e Mauro Almeida (1882-1956).

\section{Maxixe ou Marcha? Marcha ou Maxixe"?}

Os sambas de Ismael, Nilton, Bide e Marçal sugerem a mudança do acento para o segundo tempo bem como a presença de uma sessão de instrumentos de percussão.

Em conversa informal o percussionista paulista Ari Colares aponta que o samba dos anos 1930 ganhou o que chamamos de "telecoteco", ou seja, uma batida transferida ao tamborim que se completa a cada dois compassos de dois tempos, respeitando uma ideia rítmica que acaba por orientar o fraseado (em Cuba, chamado de clave e nos EUA de time line).

\footnotetext{
${ }^{11}$ https://www.youtube.com/watch?v=8_KKiSPzz9Y, acessado em 13/12/2014.

12 Daí a discussão entre Donga e Ismael, gravada pelo Museu da Imagem e do Som por Sérgio Cabral, onde Ismael diz que o samba de Donga é maxixe e Donga retruca dizendo que o samba de Ismael é marcha.
} 
Abaixo, uma ideia da condução do tamborim, que pode sempre ser de outra forma, pode variar. Notemos que este telecoteco sempre se organiza no espaço de dois compassos 2/4:

\section{Exemplo 3}

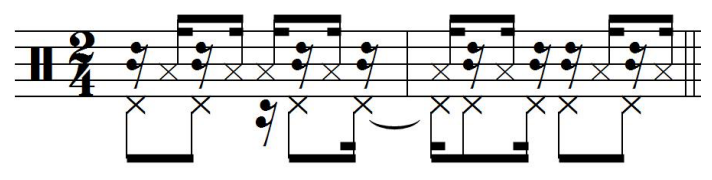

Ari Colares aponta a semelhança desta rítmica do tamborim à condução do gan, tambor usado no candomblé. Aqui um exemplo do gan tocando uma Cabula:

Exemplo 4

\section{Cabula}

Gan

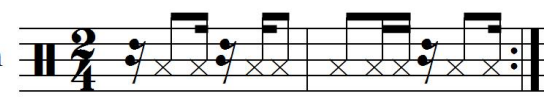

ou na sessão rítmica completa

Exemplo 5

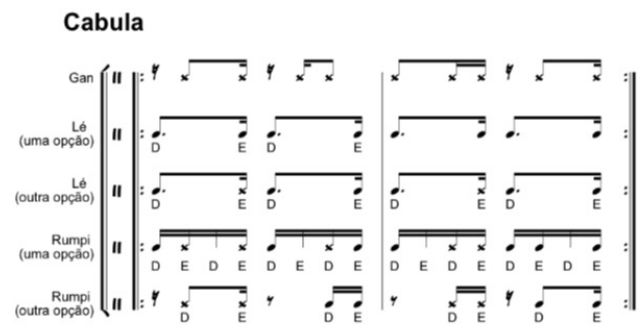

Se juntarmos esta ideia do telecoteco a uma audição atenta, perceberemos uma mudança de acentuação para o segundo tempo, que se processou em "Nem é Bom Falar". Estas duas mudanças somadas são realmente uma reviravolta no conceito de balanço do samba. O próprio Zeca Pagodinho quando gravou "Jura”, de Sinhô, gravou-o com a concepção do samba moderno, 
ou seja, o samba surgido no Estácio nos anos 1930, com o acento no segundo tempo, modificando então a ideia do samba maxixado para esta nova maneira de se tocar o samba.

\section{No balanço geral, outras bossas}

A Bossa Nova foi uma das maiores renovações estéticas da Música Popular Brasileira. Disso ninguém discorda. Muitos Ihe atribuem uma forte influência do Jazz por conta das harmonias sofisticadas levadas inicialmente ao público pelo violão de João Gilberto (1931-) e o piano de Tom Jobim (1927-1994).

A pergunta primeira que fazemos seria: influência de qual Jazz? Pela harmonia seria do Jazz da costa leste, o que parece não ser verdade se olharmos para momentos antes ocorridos na Música Popular Brasileira.

Houve sim a influência do Jazz da costa oeste, do Cool Jazz, cujo representante mais conhecido teria sido Chet Baker (1929-1988) e esta influência se operou na redução da cor orquestral, na diminuição da presença da orquestra na formação da sonoridade da canção. Com orquestrações reduzidas, a Bossa Nova resgatou novamente o Samba em seus aspectos sonoros e rítmicos com a presença do violão no centro da cena (reparemos a predileção de João Gilberto por gravar Ary Barroso e Geraldo Pereira). Fez ainda a ruptura com o romance como forma de narrativa poemática.

A orquestra passou a atuar mais como uma moldura sonora que como o corpo sonoro da canção e, inicialmente, rompeu-se com a ideia do interlúdio instrumental presente no Samba Canção. Ouvindo "Chega de Saudade”, de Tom Jobim e Vinícius de Moraes (1913-1980), ficam claras essas proposições. Há então uma mudança de música orquestral do Samba Canção para música de câmara da Bossa Nova.

Agora, a grande atitude da Bossa Nova não teria sido a colocação da tensão harmônica na voz como em "Samba de uma nota só”, Garota de Ipanema e "Desafinado"? ${ }^{13}$

\footnotetext{
${ }^{13}$ Observação feita pelo prof. Dr. Hermilson Garcia do Nascimento, o Budi Garcia, professor de guitarra elétrica da Faculdade de Música Popular da UNICAMP.
} 
Em “Samba de Uma Nota Só" temos uma nota melódica que se repete enquanto a harmonia vai caminhando do agudo para o grave. Com os acordes se modificando e a melodia se mantendo na mesma nota temos uma constante mudança da tensão harmônica, só que esta focada na melodia. Em Garota de Ipanema a melodia começa na nona do acorde. Já em “Desafinado”, a sílaba final da primeira frase cantada é uma quarta aumentada sendo esta, neste momento, a nota de maior tensão no acorde ("se você disser que eu desafino amor"...).

Durante defesa de doutorado de Paula Valente ${ }^{14}$, o músico Toninho Carrasqueira $^{15}$ afirmou ser a colocação da tensão harmônica na melodia uma característica comum ao Choro. Tendo muitas vezes a harmonia triádica, as dissonâncias eram sempre colocadas na melodia cantada ou executada por algum instrumento melódico.

Percebe-se assim que a Bossa Nova recuperou um procedimento que já se encontrava presente na Música Popular Brasileira.

Se nos ativermos à utilização da harmonia na música popular brasileira, perceberemos que o que os bossa novistas fizeram foi popularizar procedimentos harmônicos que já eram material de uso comum aos músicos brasileiros como Radamés, Garoto (1915-1955), Laurindo de Almeida (1917-1995) e Valzinho (1914-1980), sendo este último violonista da Rádio Nacional durante aproximadamente trinta anos.

Ora, Garoto faleceu em 1955 e sua obra para violão, composta antes desta data, já caminhava em direção a uma apropriação até arrojada do uso das harmonias. "Sinal dos Tempos", “Debussyana”, "Um Rosto de Mulher” e muitas outras de suas composições já apontam para este caminho muito antes da Bossa Nova.

Se ouvirmos "Braziliance" de Laurindo de Almeida, constataremos o mesmo, ou seja, de que essas harmonias já eram moeda corrente no meio musical brasileiro.

\footnotetext{
${ }^{14}$ Defesa de doutorado da flautista e saxofonista Paula Valente, ocorrida na ECA-USP no primeiro semestre de 2014.

${ }^{15}$ Professor (USP), flautista e pesquisador da música popular.
} 
Poderíamos pensar em Garoto e Laurindo como um dos pilares da moderna música popular brasileira? Se sim, o outro pilar poderia ser Dorival Caymmi (1914-2008) que, dialogando incessantemente com a cultura popular que o cercava, criou temas de extrema simplicidade amparados por harmonizações diferenciadas como em seu primeiro disco "Canções Praieiras", de 1954 ?

A utilização de motivos do cotidiano local, beira-mar, a prosódia calcada em cantos de trabalho, como em "Pescador", revelam as matrizes e fontes onde Dorival Caymmi sempre bebeu. Como essa canção, várias outras de seu disco Canções Praieiras, de 1954.

\section{Exemplo 6}

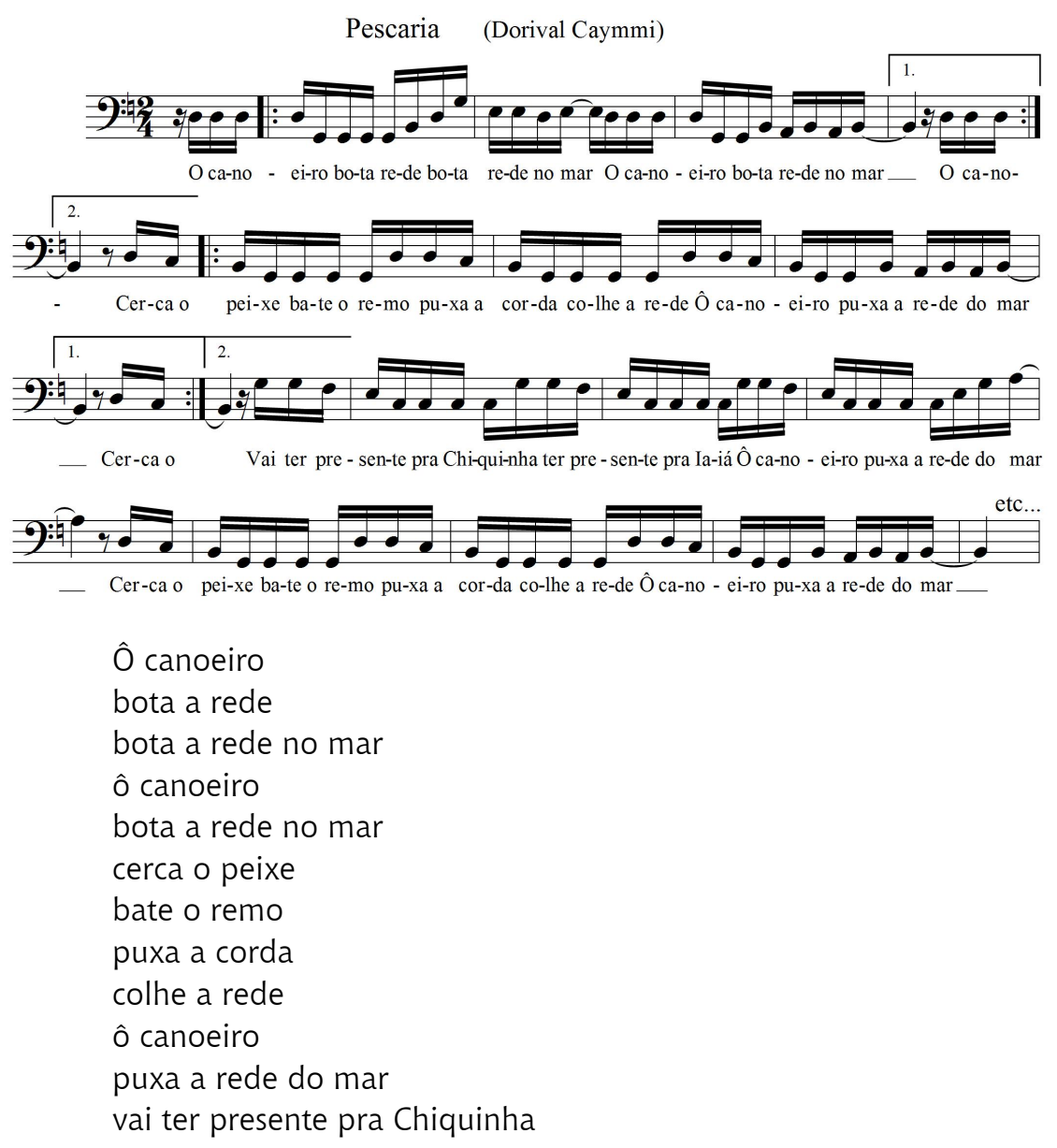


ter presente pra laiá

ô canoeiro puxa a rede do mar

Louvado seja Deus, ó meu Pai

Louvado seja Deus, ó meu Pai...

Nos versos abaixo, da canção "Pescaria", de Caymmi, reparamos a prosódia, de uma canção de trabalho, sendo prosódia o ritmo da fala e sendo o canto de trabalho uma canção que impõe ritmo aos movimentos físicos realizados pelos trabalhadores em seus ofícios (ex.: canção de pedreiro, corte de cana, fiar, carpir, lavar etc.).

"cerca o peixe/bate o remo/puxa a corda/colhe a rede".

Caymmi manteve seu trabalho de composição com um pé na observação e na apropriação da cultura popular de forma criativa, ou seja, nunca copiando-a, mas sempre renovando-a em seus motivos musicais.

\section{Novamente Debussy}

Em 2010, eu gravava no disco de Renato Braz um arranjo de Dori Caymmi (1943-). Num intervalo da gravação, sugeri a Dori minha sensação auditiva de que seu pai, no supracitado disco, trazia forte influência de Debussy em seu violão - lembremos que "Canções Praieiras" foi gravado apenas com voz e violão. Dori me respondeu: “Papai adorava Debussy. Era uma das coisas que ele mais ouvia".

Radamés cita Debussy, os jazzistas citam Debussy, Dorival ouvia Debussy, o cinema estadunidense se apropriou de Debussy.

Num momento de ruptura de conceitos musicais na música clássica em fins do século XIX e início do século XX, Debussy não foi aproveitado mais que Schoenberg para dar continuidade ao caminho de inovações nesta música. Debussy, sim, serviu de base a toda a estruturação das músicas populares no continente americano.

Este papo sobre o fim do tonalismo é contestado, na prática, pelas músicas populares do continente americano. O fato de a música clássica não ter querido continuar trabalhando no sistema tonal que se reabre em Debussy não 
significa que este sistema tenha se esgotado. As apropriações e inovações rítmicas e modais de cada região das Américas deram um novo frescor a este sistema.

\section{A canção de protesto}

Sempre que nos referimos à Canção de Protesto, estabelecemos ligações históricas dela com os vários movimentos da juventude socialista que ganharam força no Brasil nos anos 1960 como a JEC (Juventude Estudantil Cristã), a JOC (Juventude Operária Cristã e a JUC (Juventude Universitária Cristã), os CPCS (Centros Populares de Cultura) e sobre isso muito já se escreveu.

Recentemente, a pesquisadora Tânia da Costa Garcia organizou um livro ${ }^{16}$ onde escreveu um artigo levantando questões sobre um movimento de reafirmação das raízes dos povos da América do Sul. Relata que Violeta Parra (1917-1967), em fins dos anos 1940 e início de 1950 voltou-se para a interpretação de cantigas do folclore chileno chamando com esta atitude a atenção das classes artística e intelectual chilenas para a riqueza que jazia nessas manifestações.

Numa segunda etapa começou a compor canções inspiradas no folclore chileno. Na Argentina, Atahualpa Yupanqui (1908-1992) fez o mesmo movimento de forma que em 1963 foi lançado por Armando Tejada Gomez (1929-1992) “EI Manifiesto del Nuevo Cancionero" que preconizava, dentre vários postulados, a defesa da integridade latinoamericana ante à invasão e dominação cultural dos EUA, que no pós Segunda Grande Guerra se intensificara ante a América Latina.

O Cancioneiro de Gomez sugeria que o folclore das nações latinoamericanas deveria ser a base de renovação da canção desses países e que o folclore, como manifestação semovente que é, deveria acompanhar as mudanças desses tempos. A afirmação cultural surgia aqui pela olhar às raízes.

Tânia Garcia estabelece uma ligação da canção de protesto brasileira com este movimento que aflorava do sul para o norte do continente sul americano,

\footnotetext{
16 Música e Política, org. Tânia da Costa Garcia e Lia Tomás, São Paulo, Alameda Casa Editorial, 2013.
} 
lançando uma luz que aproxima a realidade brasileira da realidade sul americana. A maioria dos musicólogos brasileiros sequer falaram desta suposta ligação, como se o Brasil insistisse em andar de costas para a América Espanhola.

É fácil de entendermos esta postura uma vez que sempre se tratou a música produzida na capital federal, o Rio de Janeiro, como o protótipo e praticamente a única representante da Música Popular Brasileira. Notemos que tudo que era produzido fora do eixo Rio - São Paulo - Salvador foi tratado sempre como música regional, termo que refuto com força, pois mais que um designativo, o termo regional tornou-se um termo qualitativo. Jamais trataríamos o disco "Canções Praieiras" de Dorival Caymmi como um disco de música regional embora ele cante o cotidiano dos pescadores da Bahia. O mesmo ocorre com “Grande Sertão: Veredas”, de João Guimarães Rosa, que de obra absolutamente regional passou a ser universal dada a sua qualidade.

Assim, quando a obra não atinge uma envergadura tal que a torne nacional ou universal, ela, quando produzida fora do eixo acima citado é sempre tratada como regional. ${ }^{17}$ Curiosamente tratamos Elomar como música regional e, na realidade, ele faz com a caatinga o que Dorival fez com o mar.

Voltando à ideia proposta por Tania Garcia, fica mais razoável entendermos o movimento da Canção de Protesto no Brasil como uma decorrência natural de vozes que se levantavam para narrar o cotidiano de seus povos ante uma dominação que de cultural passou a ser, posteriormente, militar.

Como herança à MPB atribui-se à Canção de Protesto as letras revolucionárias e a narrativa de um Brasil que pouco foi mostrado na estampa central de nossa música popular.

Mais que temáticas de protesto narradas, este movimento da Canção de Protesto trouxe inúmeros novos elementos à canção popular que sequer foram

\footnotetext{
17 "Se isso é um fato, também parece verdade que o regionalismo está sendo entendido aí como uma restrição qualitativa que, no limite, invalida conceitualmente a própria categoria, pois tudo poderia resumir-se à seguinte fórmula: quando a obra não atinge um certo padrão de qualidade que a torne digna de figurar entre os grandes nomes da literatura nacional, ela é regionalista; quando, pelo contrário, consegue atingir este padrão, ela não seria mais regionalista, seria uma obra da literatura nacional, reconhecida nacionalmente e, até mesmo, candidata, como é o caso de Guimarães Rosa, a um reconhecimento supranacional, para não dizer universal" (Chiappini, 1994, p. 699).
} 
relevados como importantes. E aqui vale entendê-lo como um movimento na medida em que houve, em um mesmo período, um levante de vozes diversas por todo o Brasil cantando a realidade de cada povo, de cada cultura existente no país.

Novos timbres, novos ritmos e novas estruturas modais foram inseridas na corrente central da MPB que tinha a Bossa Nova como o padrão referencial sonoro. $^{18}$

Se a Bossa Nova alavancou o reflorescimento da música instrumental no Brasil pela via dos jazz trios, será no Quarteto Novo, ${ }^{19}$ 1967, que surgirá uma nova opção de uso da canção instrumental no Brasil. Lembremos que o Choro sobrevive desde os anos 1930 não como uma música de grande vendagem.

A linguagem musical apresentada por este grupo apontou para uma música de caráter universal construída a partir de elementos das culturas nordestinas aos quais estavam inseridas todas as aquisições obtidas pela MPB ao longo de sua história. Contraponto rebuscado, mudança de textura, de andamentos, de densidade instrumental, alternância de compassos de dois tempos, 2/4, para compassos de sete tempos, 7/8, harmonização complexa mesclando o tonal com o modal, inserção da viola brasileira junto a uma percussão construída por caxixi e queixada de burro junto à bateria.

O Quarteto Novo tornou-se uma chancela sonora aos intérpretes e compositores que queriam dar um ar de Brasil de Dentro ao seu trabalho. Geraldo Vandré e Edu Lobo foram dois desses cantautores.

Voltando ainda à Canção de Protesto e ao Manifiesto del Nuevo Cancionero, fica evidente a atuação de músicos como Dércio Marques e Doroty Marques e todo o movimento de música mineira dos anos 1980, como uma

\footnotetext{
18 Se ouvirmos os primeiros discos de Milton Nascimento, alguns dos primeiros discos de Chico Buarque e Edu Lobo, perceberemos que esta sonoridade mais afeita ao cool jazz, era a sonoridade usual dos artistas que faziam parte do seleto clube da MPB que, acreditava-se, havia se consolidado enquanto um campo de conquistas musicais dentro de uma linha evolutiva.

${ }^{19}$ Grupo formado por Airto Moreira, Heraldo do Monte, Hermeto Paschoal e Théo de Barros.
} 
continuidade deste movimento no Brasil. ${ }^{20}$ Lembremos que Dércio e Doroty estiveram ligados ao selo Marcus Pereira. ${ }^{21}$

Vejamos a canção “Arreuni”, de Chico Maranhão (1942-), gravada por Doroty Marques em seu disco Erva Cidreira, de1980.

Antonce se a gente veve lutando Antonce a gente deve se arreuni Antonce se a gente veve lutando Vale mais, vale mais, ô vale mais A gente se arreuni

Antonce se a gente já veve lutando Antonce eu peço pra gente se arreuni

Vá buscá meu rifle ali

Meu rifle cor de canela

Vá buscá meu parabelum

E limpe a madrepérola

Antonce se a gente veve em paz

Vale mais, vale mais, ô vale mais

Antonce a gente veve brincando

Antonce se a gente veve brincando

Antonce a gente torna se juntá

Tem que avisá todos colegas

Tem que avisá

Dô no corte de uma faca cega

Pra nos fiá

Antonce se a gente veve em paz

Vale mais, vale mais, ô vale mais

Ou antonce é uma grande tristeza

Antonce se tem tristeza montando

Antonce arrede o pé desse amo

Vou furar o sol numa trincheira

\footnotetext{
20 Por todo o Brasil criou-se uma rede de cantautores que cantam a sua região. Existe uma relação de contato, as vezes estreito, entre estes músicos de diversas localidades do Brasil. Dércio Marques foi o principal articulador e agregador desses músicos por todo o Brasil.

${ }^{21}$ Marcus Pereira foi um publicitário que, após viajar pelo Brasil, resolveu criar um selo musical que registrasse a música do Brasil de Dentro. Produziu 166 LPs trazendo à luz valores musicais de todo o país.
} 
Dos oceano

Com uma bala de prata certeira

Que eu fiz e lhe mando

Antonce se a gente veve em paz

Vale mais, vale mais, ô vale mais

Antonce a gente segue lutando

Pela audição das canções ligadas a este segmento percebemos que o espectro de ação e herança de elementos musicais legados à MPB pela Canção de Protesto foi bem maior do que se aponta usualmente.

\section{Estilhaço pós-tropicalista?}

A crítica musical no Brasil exerceu um papel importante na definição dos estudos acadêmicos, pois foi a partir dessas críticas que se orientaram os primeiros estudos musicológicos surgidos na academia, no Brasil.

Ela sempre soube muito bem apoiar suas análises sobre o novo que surgia, conflitando com o que havia ocorrido anteriormente, ou seja, fica fácil percebermos as mudanças propostas pela Bossa Nova se a colocarmos ao lado do Samba Canção.

A Jovem Guarda ganha perfil definido se a ligamos com o movimento de internacionalização do Rock and Roll que chegou ao Brasil apoiado pelo movimento da Contracultura e pela indústria do disco já ligada à um conceito de cultura de massas.

Aqui uma idiossincrasia: a Jovem Guarda preconizava uma modificação nos costumes e atitudes embora fosse absolutamente atrelada à máquina, já potente, da indústria cultural que passava a cobrir revistas, jornais, rádios e tevês.

Com faixada de revolucionários dos comportamentos, aderiram inocentemente a ícones do capitalismo como ter um carrão, percepção ainda operante no Brasil nos dias de hoje. Preconizavam uma liberalização dos costumes e comportamento, embora a cantora Wanderléa, quando fora da cena artística, se mantivesse como uma garota comportada. 
Olhar a Tropicália, do ponto de vista musical nos traz à revisão dos movimentos anteriores, ou seja, uma revalorização da Jovem Guarda como representante de um inexorável movimento de internacionalização da cultura brasileira - ouvir a canção "Baby", de Caetano Veloso (1942-) -, o resgate do romance como narrativa poemática que havia sido abolido pela Bossa Nova ouvir "Domingo no Parque", de Gilberto Gil (1942-) - e o resgate do Brasil de Dentro nos ritmos - baião, frevo dentre outros - e também estruturas modais nas canções de Caetano Veloso, a começar na canção "Tropicália".

Musicalmente, a Tropicália trabalhou com essas fusões junto à música e à poesia concreta. Lembremos que o rock dos nos 1960 dialogou com a música clássica contemporânea que assumira inúmeras derivações a partir de Pierre Schaeffer; algumas ligadas à eletrônica como foi o caso de Stockhausen.

Rogério Duprat, arranjador principal deste movimento, trabalhou com colagens musicais $^{22}$ em seus arranjos, atitude coerente com os modelos da Pop Art.

Assim, a crítica sempre soube o que dizer acerca do novo, se apoiando sempre no velho, digo, no anterior.

Agora uma dúvida: E quando surge o Clube da Esquina, que sequer é tratado como um Movimento dentro do rol de acontecimentos na MPB?

$\mathrm{O}$ frescor de suas ideias fez a crítica se calar, pois ao mesmo tempo em que trazia em seu bojo todas as conquistas musicais adquiridas ao longo da história da MPB, conseguia não parecer com nada que havia acontecido antes.

\section{Síntese}

O Clube da Esquina não trabalhou com colagens, mas sobretudo com sínteses. Síntese nos remete a misturas, amálgamas, onde não conseguimos identificar os ingredientes dentro do produto final. A grande síntese da Música Popular Brasileira se operou com e a partir do Clube da Esquina. É esta a palavra para começarmos a entender o Clube da Esquina como possivelmente o

22 Em suas orquestrações percebemos trechos de outras músicas. 
movimento que mais inseriu novos elementos na MPB na década de 1970. Os discos Milton, 1970. Clube da Esquina, 1972. Milagre dos Peixes, 1973. Minas, 1975 e Geraes, 1976, foram responsáveis pela inserção de novos procedimentos na MPB. Nota-se a presença da harmonias complexas, mas não se liga elas exatamente a algo anterior. Milton Nascimento (1942-), falava de sua santíssima trindade do Jazz - Charles Mingus, John Coltrane e Miles Daves -, porém, não escutamos trechos desses compositores de forma evidente em suas músicas.

Toda a representação afro-brasileira na MPB foi mantida pelo Samba. Milton trouxe a África Mineira à MPB, o canto dos negros ligados ao Congado. ${ }^{23} \mathrm{~A}$ ponte com a canção latino-americana foi feita por ele a partir do disco Clube da Esquina e reforçada nos discos Milagre dos Peixes e Geraes.

O uso de um violão harmônico-percussivo de batidas arrítmicas e faixa dinâmica de grande amplitude, só presente, até então na música clássica. A construção de grandes arranjos onde percebemos a existência de muitas camadas sonoras independentes e o uso da percussão não como uma cozinha rítmica, mas sim como um evento de vida própria, concorrente à canção.

Em relação à percussão foi o Clube da Esquina o primeiro a utilizar a percussão com um volume maior que o da própria voz como na canção "Caxangá", de Milton Nascimento e Fernando Brant (1946-), gravada no álbum Milagre dos Peixes. Vemos também um alargamento da estrutura formal em "Hoje é dia de El Rey", de Milton Nascimento e Márcio Borges (1946-), do mesmo disco Milagre dos Peixes.

O uso do falsete não como um recurso final onde não se alcança mais a voz em seu registro natural, mas sim como um novo recurso tímbrico. Ouvir a canção Lilia, de 1972.

Se nos ativermos ao primeiro disco de Beto Guedes (1951-), “A Página do Relâmpago Elétrico" perceberemos uma timbragem até então inexistente na música pop, produzida principalmente por um bandolim ligado a um pedal "phaser".

${ }^{23} \mathrm{O}$ Congado mineiro tem sete manifestações, quais sejam, candombe, catopé, congada, moçambique, marujada, vilão e caboclinhó, este último chamado de caiapó no Sul de Minas. 
O arranjo ganhou, com o Clube da Esquina, uma dimensão inédita na MPB. Inserção de sons que podemos chamar de psicodélicos diferentes dos usados pelos Mutantes.

Na canção “Trastevere”, de Milton Nascimento e Ronaldo Bastos (1948-), do disco Minas, desconstruiu-se o conceito de melodia, harmonia e ritmo como acompanhantes do melopoema. ${ }^{24}$ Criou-se uma massa sonora, como uma nuvem de sons aparentemente aleatórios que agasalham de forma inusitada o melopoema.

As letras, mais que narrar histórias ou pintar situações, ganharam um outro espectro de imagens, como se quisessem dizer algo além do texto escrito.

A utilização de inúmeras fórmulas de compassos numa mesma música como a canção "Cruzada”, de Tavinho Moura (1947-) e Márcio Borges, onde temos na parte cantada um compasso 2/4, um compasso 3/8, dois compassos 2/4, um compasso $5 / 8$ e depois seguindo em $2 / 4^{25}$. O curioso é que não percebemos as quebras na melodia que se desenrola macia, lisa. Ainda em relação aos compassos, Milton compôs, com Fernando Brant, em compasso de cinco tempos, 5/8, sem aparente quebras de 2 e 3 ou 3 e 2, a canção "Saudade dos Aviões da Panair".

Exemplo 7

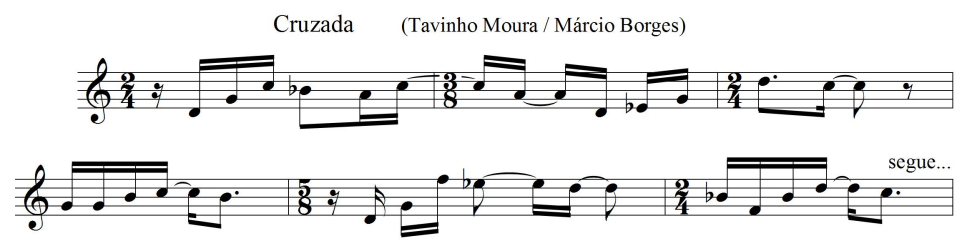

Caminhos harmônicos novos foram sugeridos principalmente por Milton, Toninho Horta (1948-) e Nelson Ângelo (1949-). Arrojo e experimentalismo são material comum em todos esses discos.

\footnotetext{
${ }^{24}$ Melopoema seria a melodia e a letra despidas do arranjo. Termo cunhado por mim.

${ }^{25}$ Gravação de Beto Guedes no disco Sol de Primavera, 1979.
} 
Uma certa promiscuidade musical que fazia os músicos trocarem seus instrumentos por outros que habitualmente não utilizavam acabou resultando numa sonoridade de característica étnica. Explico: quando Wagner Tiso (1945-) grava ao piano temos ali o melhor do som que pode ser produzido neste instrumento. Quando Milton ou Toninho Horta, que são violonistas, gravam ao piano a sonoridade perde em exuberância e ganha em um novo jeito de se tocar, de se abrir os acordes. Perto da execução esperada, surge um som quase sujo. Beto Guedes gravou bateria, Milton, piano, Lô Borges (1952-), piano e percussão, Toninho Horta, baixo acústico. Novas características tímbricas foram trazidas à cena.

Não seria este um dos pressupostos da World Music? Perceber que uma rabeca, longe de ser um violino que não deu certo, é um outro instrumento, um outro timbre?

Se pensarmos em World Music como um conceito musical que cria um amálgama entre elementos de culturas locais, étnicos, com a música pop, veremos que o disco Clube da Esquina, de 1972, foi o precursor deste conceito, muito antes de Paul Simon (1941-).

Todas essas novas informações acrescentadas ao meio musical tornaram-se material de uso comum na MPB e em nenhum momento atribuiu-se ao Clube da Esquina a inserção desses elementos. Sequer foram tratados como um movimento musical.

Cabe aqui uma pequena observação sobre o cânone. Até que ponto acessamos pela mídia algo que não seja tratado como um cânone? Corremos o perigo de achar que os acontecimentos canônicos foram os únicos existentes, esquecendo que o que fez e faz a Música Popular Brasileira ser ainda a grande música popular do mundo não é apenas a qualidade de sua produção, mas pincipalmente a sua ampla diversidade.

A ideia do cânone nos fez chamarmos a canção "Cravo e Canela", de Milton Nascimento e Ronaldo Bastos, de samba em três, por ser ela um balanço em $3 / 4$. Ora, isto é um congado e trazer a música mineira para uma esfera do samba é ler uma cultura com a lente da outra. Isto se chama etnocentrismo e, nós 
brasileiros, frequentemente recorremos a este equívoco para entendermos, reduzirmos, o que não sabemos claramente.

A crítica, não entendendo a mensagem musical do Clube da Esquina, pouco escreveu sobre ele e, posteriormente, toda uma ordem de estudos acadêmicos que tiveram as críticas como primeira fonte de pesquisa, não foram realizados. Basta escrevermos num buscador de internet: tropicália pdf ou Bossa Nova pdf para constatarmos a enorme quantidade de estudos feitos. Agora, escrevendo Clube da Esquina pdf perceberemos quão parca é a ordem de estudos sobre este acontecimento musical ocorrido no Brasil.

Mesmo apresentando todas essas inovações, um musicólogo, desavisado ou tendencioso, em livro sobre a Tropicália se referiu ao Clube da Esquina como um estilhaço pós-tropicalista.

Francamente. Muitas dessas músicas já haviam sido gestadas antes do próprio tropicalismo ser anunciado como um movimento em 1967.

Espero, mais que resolvido questões, ter levantado dúvidas com este pequeno ensaio.

Diante dessas colocações insisto que quando se fala de música, seja ela cantada ou instrumental é mister que se escute as fontes primárias, ou seja, os discos. A experiência da fruição entra aqui como um procedimento imprescindível no escrever sobre música, pois a percepção obtida disso amplia o entendimento do objeto. Fazer musicologia somente a partir de livros pode ser perpetuar, desavisadamente, equívocos que foram registrados por outros musicólogos, anteriores.

\section{Referências}

BONDÍA, Jorge Larrossa, Notas sobre a experiência e o saber de experiência, Revista Brasileira de Educação, Jan/Fev/Mar/Abr, 2002 nº 19.

BRESSON, Bruno Cartier. Uma história que conta como os violinos chegaram aos arranjos do samba, in O Estado de S. Paulo. 19/03/1979, p. 26.

CALADO, Carlos.1997. Tropicália: a história de uma revolução musical. São Paulo. Editora 34. 
CAMPOS, Augusto de. 1978 (3a edição). Balanço da bossa e outras bossas. São Paulo, Editora Perspectiva.

COLOMBRES, Adolfo. 1995. Palabra y artifício: las literaturas "bárbaras" in PIZARRO, Ana (org.) América Latina palavra, literatura e cultura. Campinas, Editora da Unicamp.

FERNANDES, Florestan. 1979. Folclore e mudança social na cidade de São Paulo. Petrópolis, RJ, Vozes.

GARCIA, Tânia da Costa. 2013. Redefinindo a nação. Canção poular e folclore: um estudo comparativo entre Chile, Argentina e Brasil no pós-segunda guerra mundial. in GARCIA, Tânia da Costa e TOMÁS, Lia, (org). Música e Política. São Paulo. Alameda Casa Editorial.

CHIAPPINI, Lígia Moraes Leite. 1995. Velha Praga? Regionalismo Literário Brasileiro" in PIZARRO, Ana (org.) América Latina palavra, literatura e cultura. Campinas, Editora da Unicamp.

SAHLINS, Marshall. 1988. Cosmologias do Capitalismo. Campinas, SP, Conferência na XVI Reunião da Associação Brasileira de Antropologia. Anais ABA.

SANDRONI, Carlos. 2001, Feitiço Decente - transformações no samba no Rio de Janeiro (1917-1933). Rio de Janeiro. Jorge Zahar Editor/Editora UFRJ.

SANT'ANNA, Afonso Romano de. 1978. Música Popular e moderna poesia brasileira. Petrópolis, Vozes.

TATIT, Luiz. 1995. O cancionista. São Paulo, Edusp.

TINHORÃO, José Ramos. 1990. História social da música popular brasileira. Lisboa, Editorial Caminho.

VILELA, Ivan. 2013. Cantando a própria história - música caipira e enraizamento. São Paulo, EDUSP. 